\title{
Predictors of fast-fashion-oriented impulse buying: The case of Vietnamese millennials
}

\section{Son Truong Nguyen ${ }^{\mathrm{a}}$ and Tri Minh $\mathrm{Ha}^{\mathbf{b}^{*}}$}

${ }^{a}$ Eastern International University, Vietnam

${ }^{b}$ International University, Vietnam National University - Ho Chi Minh City, Vietnam

\section{H R O N I C L E}

\section{Article history:}

Received: December 14, 2020

Received in revised format:

January 292021

Accepted: March 9, 2021

Available online:

March 9, 2021

Keywords:

Fast fashion

Fashion-oriented impulse

purchase

External and internal stimuli

Hedonic value

Store environment

Fashion involvement

Emotion

\begin{abstract}
A B S T R A C T
During the last few years, global fast fashion retailers have been penetrating Asian emerging markets and Vietnam is not an exception. This study explores both external and internal factors, contributing to the fashion-oriented impulse buying of Vietnamese millennials and then investigates the impact of these determinants on fashion-oriented impulse purchase. Both qualitative and quantitative approaches were conducted in the empirical study. It is found that emotion and hedonic value along with fashion involvement, sensory cues and in-store promotion respectively influence fast-fashion oriented impulse purchase. These findings help fast fashion retailers understand the impulse buying behavior of young Vietnamese consumers so that they can effectively elaborate retailing-mix strategy to boost the sales and thus sustainably grow the business.
\end{abstract}

\section{Introduction}

Fast fashion has become a trend in recent years among Asian emerging markets such as China, India, and Vietnam after being revolutionized in the early 1990s in Western Europe (Hu \& Shiau, 2015). The attractiveness of fast fashion can be explained by the latest trend and low price just after a short period being appeared in fashion shows (Morgan \& Birtwistle, 2009). The exceptional development of this new business model in the fashion industry is attributed to strong impulse purchase, vertical integration of production in low-cost countries and the changing consumer behavior as well (Barnes \& Lea-Greenwood, 2010; Morgan \& Birtwistle, 2009). During the past few years, most of global fashion brands such as Old Navy, UNIQLO, Zara, H\&M, etc. have penetrated Asian emerging markets including Vietnam. Moreover, Vietnam has witnessed the increasing income per capita leading to growing disposable income in the context of economic recovery in conjunction with its young population who has been particularly changing their behavior toward fast fashion goods and that has made Vietnam a hub for global fashion retailers. Previous studies have found out that fashion clothes make purchase important and most of fashion outfit goods' purchase is impulse purchase (Zhou \& Wong, 2003). As a result, fashion retailers can improve significantly their sales by enhancing impulse buying behavior when customers shop at their stores. Even though impulse purchase has been intensively researched in developed countries in the last two decades, it has become a new field of study, particularly in the fashion industry in Asian emerging markets such as Vietnam, Indonesia and China (Nguyen, Jung, Lantz, \& Loeb, 2003; Yu $\&$ Bastin, 2010). Fast fashion research is quite recent and mainly focuses on the fast fashion producer perspective in terms of vertical supply chain combining a growing concern about corporate social responsibility rather than on the consumer

* Corresponding author.

E-mail address: hmtri@hcmiu.edu.vn (T. M. Ha) 
perspective (Barnes \& Greenwood, 2010). In Asia, fast fashion consumer behavior has just emerged in Asia during the 2010s (Hu \& Shiau, 2015; Khare \& Rakesh, 2010; Patil \& Agadi, 2016). Meanwhile, fashion buying behavior research is quasiinexistent in Vietnam. This research work attempts to investigate the relationship between factors, both internal and external, that might influence the fashion-oriented impulse purchase among Vietnamese millennials who represent the key target segment of fast fashion sector. The study contributes to advance our understanding the relationship between fashion-oriented impulse purchase and its antecedents as it helps fashion retailers elaborate effectively the retailing-mix strategy to operate successfully in such a strongly competitive fashion market like Vietnam.

This study also aims to theoritically contribute to the extant literature by re-examining and adding new understanding toward one of the internal factors, namely "hedonic value", definied as the enjoyment of the shoppers while shopping in stores that significally drives the impulse buying decision of Vietnamese consumers. One of the aspects of hedonic consumers is that they are willing to buy on impluse when "highly interacted and praised" by their shopping accompanies, namely other shoppers. In the Vietnamese context, the study proposes that the more crowded environment (with more lingering shoppers producing more interactions), the more likability that the impulse purchase is more triggered due to the "crowd effects" which have already confirmed nagatively by previous studies, mostly in Western cultures. The paper is organized in four parts. The first part briefly introduces a brief landscape of the fast fashion market in Vietnam. The second part presents a brief literature review on fashion oriented impulse buying in relationship with its antecedents including external and internal stimuli. The third part describes the research design and findings. Lastly, part four ends up with managerial aplications, conclusions and future research.

\section{Literature review}

\subsection{Impulse buying concept}

In the consumer behavior field, impulse buying is a common phenomenon that has been studied for nearly 70 years with the pioneer study of Clover (1950) who identified the important role of impulse purchase in the retailing settings. Since then, a large body of research on this area has been developed in Western countries before gaining interest in Asia and interestingly, impulse buying behavior literature has been recently reviewed by some Asian authors. Before 1987, impulse buying was defined as a purchase without plan focusing on the product rather than the consumers. Later on, impulse purchase was reconceptualized as a specific behavior than a simplistic unplanned behavior by incorporating its psychological aspects including excitement, pleasure and irresistible urge to buy (D. W. Rook, 1987). In this sense, rather than the products, the shoppers who experience impulse consumption (Rook \& Hoch, 1985).

\subsection{Fashion-oriented impulse buying}

With relevant literature, impulse buying behavior depends on the categories of products. Fashion clothing goods are found among products that highly induce impulse purchase. In the 1990s, impulse purchase behavior was studied through high involvement of consumers into fashion products (Han, 1991; Park, Burns, 2005; Predergast; Gutman, Mills, 1982; as cited in Virvilaitè, Saladienè, \& Žvinklytè, 2011). Beatty and Ferrell (1998) further described that fashion oriented impulse purchase is considered as an unexpected purchase without any previous plan to buy fashion products. It is also a result when a shopper responds to a variety of internal and external marketing stimuli by making decision to buy fashion products immediately without thinking about the consequences (Rook, 1987).

\subsection{Predictors of fashion-oriented impulse purchase}

External stimuli are commonly characterized as environmental and marketing-related factors while internal stimuli are shopper-related factors (Duarte, Raposo, \& Ferraz, 2013; Youn \& Faber, 2000). Predictors of fashion-oriented impulse purchase was investigated initially based on the model of impulse buying consumer behavior (Weinberg \& Gottwald, 1982). When shopping in a store, consumers are exposed to a specific environment and they are affected by various external and internal stimuli. Therefore, impulse purchase is exclusively stimuli driven (Rook \& Fisher, 1995). The extant empirical literature on the impact of stimuli on impulse purchase indicates that external and internal stimuli can directly affect the impulse purchase investigated by Nanda (2013), or indirectly via moderators (Aron, 2004; Park \& Lennon, 2006).

\subsection{External stimuli and the impact on impulse buying}

When a customer exposed to external stimuli including store environment, marketing-mix stimuli, demographics and socioeconomic factors, he or she will respond by buying or not buying impulsively (Amanda \& Brigitte, 2003; R. Virvilaitė et al., 2011; Youn \& Faber, 2000). The empirical studies are particularly paid attention on the relationship between external environmental stimuli such as atmospheric cues, in-store promotions, human factors and social interactions and impulse buying behavior (Yang et al., 2011; Kotler, 1973; Sharma, Sivakumaran, \& Marshall, 2006). 
Sensory cues refer to atmospheric cues composed of smell, sights, sound and touch can have a profound impact on impulsive consumption (Mattila \& Wirtz, 2001; Sharma et al., 2006; Sharma, Sivakumaran, \& Marshall, 2010). Atmospherics related to the ambient environment elements surrounding the customers that create the shopping atmosphere including tangible and intangible cues. The tangible variables include fixtures, cleanliness of the store, displayed colors and merchandise, and appealing decoration while intangible aspects are including temperature, scent, lighting, and music. These elements have high possibility affecting to the impulse buying of the shoppers when they engage in buying decisions (Maymand \& Ahmadinejad, 2011).

Visual merchandizing refers to the means to visual presentations that convey the brand image or the firm's value (Lee \& Yi, 2008). In regard to the case of clothing stores, the role of visual stimuli is to enhance the image of the store and to boost sales (Bhatti \& Latif, 2014; Khandai et al., 2012). Visual merchandizing dimensions are examined through both store exterior of the store such as window display, retail premises while the store interior is namely signage, layout, presentation techniques, ambient conditions, point of purchase display, floor merchandising, and shop brand name (Zhou \& Wong, 2003).

\subsection{Salespeople}

In a store, salespeople play an important role to influence customer impulse purchase. Friendly, courteous, professional, knowledgeable and supportive staff who offer extraordinary customer service appear crucial to trigger impulse purchase during their store visit (Mattila \& Wirtz, 2008; Peck \& Childers, 2006; Ridgway et al., 2008)

\subsection{In-store promotion}

In-store promotion as part of marketing stimuli can amplify the magnitude of unplanned purchasing among consumers (Liao et al., 2009). Various promotion tools at the point of purchase including discounted offerings, attractive advertisement as well as special gifts, loyalty programs, etc. are found positively correlated with impulse buying behavior (Yang et al., 2011; e. a. Virvilaite, 2011).

\subsection{Social stimuli}

Social factors involve in the number, type and behavior of people that appear within the store including other buyers and salespeople (Robert, 2001), including crowded behavior, employee attitudes, and social interaction between consumers and salespeople that can stimulate impulse buying (Turley \& Milliman, 2000). Among these social stimuli, perceived crowding was found the most influential factor of impulse purchase (Miyuri, 2017). Furthermore, according to Luo (2005), the presence and interaction of other shoppers within the store can trigger the impulse purchase.

\subsection{Internal stimuli and the impact on impulse buying}

The impulse buying's internal drivers focus directly on the individuals. Thus, considering the internal cues is a critical factor when examining impulse buying behavior (Kacen \& Lee, 2002). There are three key internal consumers' characteristics such as emotional state, hedonic value and individual fashion involvement. Internal factors of impulsive purchase examine the internal motivation and characteristics of the buyers engaging in buying on impulse. Among internal cues, researchers usually highlight emotions, hedonic shopping value, product involvement and personal traits (Kacen \& Lee, 2002; Tigert, Ring, \& King, 1976). In addition, Agarwal (2015) proved that personal traits including demographic such as gender, income can trigger impulse purchase.

\subsection{Fashion involvement}

With regard to the buying behavior, involvement is described as an interaction between a consumer and a product or service and it involves the related activities when consumers make a purchase decision (Parker, Simmers, \& Schaefer, 2014). Involvement is conceptualized as a multidimensional concept and measured by different scales (Warrington \& Shim, 2000). In relation to fashion consumption, the involvement refers to the shoppers' interest with the purchase of clothing (Aron, 2004; Pornpitakpan, Yuan, \& Han, 2017). Antecedents of fashion involvement include materialism, gender and age whereas consequences are composed of fashion subjective knowledge and consumers' confidence in decision making about fashion clothing (Aron, 2004). In empirical studies, fashion involvement is measured by scales proposed by (Aron, 2004; Tigert et al., 1976). Specifically, the study shows a positive relationship between the level of fashion involvement and purchasing fashion goods which indicates that shoppers with higher level of fashion involvement are more likely to engage in fashion impulse buying (Aron, 2004; Park \& Lennon, 2006)

\subsection{Emotion}

According to Wong and Bagozzi (2005) emotion is "the mental state that arises from the evaluation of events or thoughts of oneself". Both positive or negative emotion can affect the consumer purchase decision (Avinash \& Chinmaya, 2009; Scheier 
\& Carver, 1988). A consumer when shopping in the store with a positive mood may also affect his or her impulse buying. The emotional states of consumer such as pleasure, arousal are influenced by the environmental stimuli and this can lead to a positive approach toward purchasing (Donovan, Rossiter, Marcoolyn, \& Nesdale, 1994). Interestingly, Verplanken and Herabadi (2001) revealed that impulsive buyers are more emotional than non-impulsive ones. As a result, consumers with positive emotion would spend more money when shopping and hence are more likely to make decisive decisions faster (Lee and Yi (2008). Therefore, consumer emotion can be an important determinant to predict impulse buying of the shoppers while engaging in buying fashion goods (Beatty \& Ferrell, 1998; Cobb \& Hoyer, 1986).

\subsection{Hedonic value}

Consumer value can be categorized as utilitarian value and hedonic value that are considered by marketers as important factors to evaluate consumers' consumption experience to design effectively their marketing by a set of dimensions and items. Utilitarian consumers behave rationally while hedonic consumers seek for the sensation perceived from enjoyment from their shopping experience (Yu \& Bastin, 2010). In this sense, the possession of a product is not even the main purpose to purchase (Babin, Darden, \& Griffin, 1994). From the experiential perspective, hedonic consumption is defined as fantasy, emotional aspects of consumption, and multisensory experiences that are driven by benefit seeking when shopping such as the pleasure of using the product and aesthetic appeal such as sleeky design, appealing packaging, etc. (Geoff \& Clive, 1998). In the empirical literature, hedonic shopping value is measured by elements such as novelty, fun, praises from others, and social interactions. Other variables suggested in the research work of Činjarević et al (2011)_are environmental variables including surrounding characteristics and design. Most importantly, hedonic shopping value is found a predictor of impulse purchase (Piron, 1991; Ramanathan \& Menon, 2006; D. W. Rook, 1987).

\subsection{Proposed research model}

Past research on impulse purchase in retail environment indicates that there is no unified attitude to factors affecting impulse purchase (Balaji \& Babu, 2015). Therefore, in order to investigate factors affecting fashion-oriented impulse purchase among millennial consumers in a specific emerging market like Vietnam, we propose our research model in Exhibit 1 . Based on the literature review analyzed in the previous session, five dimensions were indentified relating to external stimuli named (1) Sensory cues, (2) Visual merchandizing, (3) Salespeople, (4) In-store promotion, and (5) Social stimuli and 3 dimensions related to internal stimuli such as (1) Emotion, (2) Hedonic value and (3) Fashion involvement. An additional dimension is incorporated to test the impact of gender and on fashion-oriented impulse purchase.

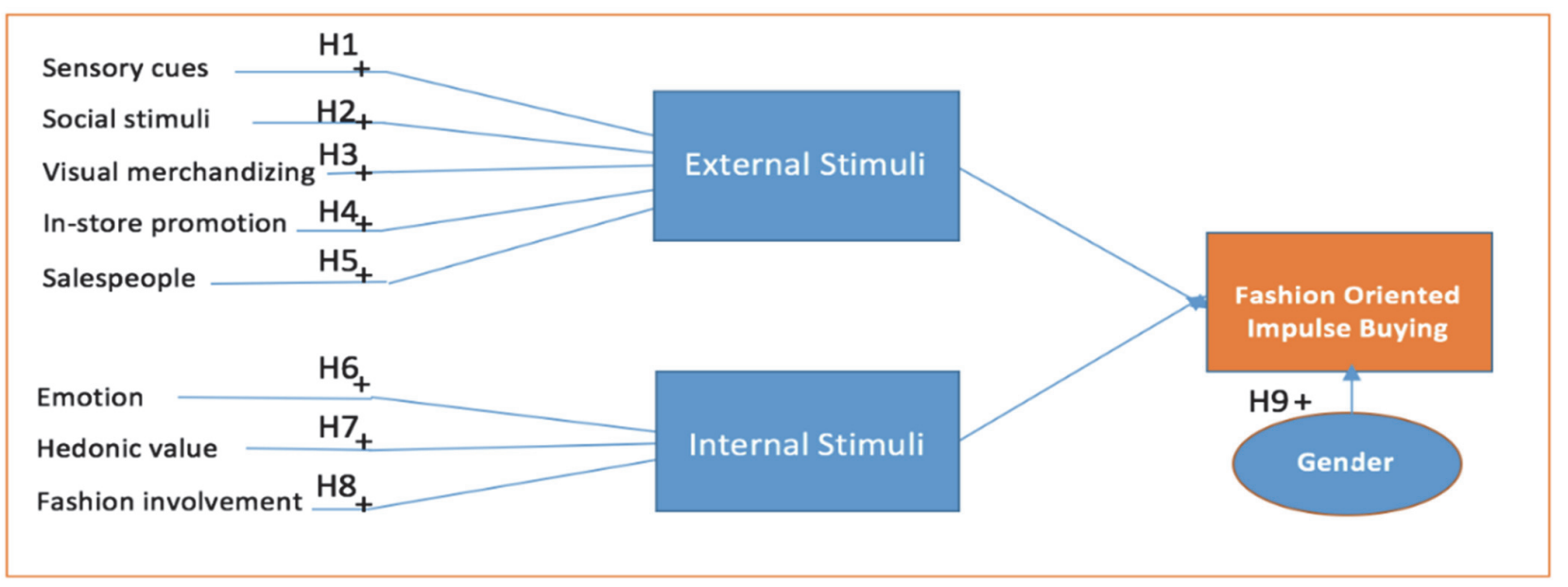

Fig. 1. Proposed research model

\subsection{Hypothesis formation}

- H1: Sensory cues positively impact on fashion-oriented impulse buying (FOIB) of Vietnamese millennials.

- H2: Social stimuli positively impact on FOIB of Vietnamese millennials.

- H3: Visual merchandizing positively impacts on FOIB of Vietnamese millennials.

- H4: In-store promotion positively impacts on FOIB of Vietnamese millennials.

- H5: Salespeople positively impact on FOIB of Vietnamese millennials.

- H6: Emotion positively impacts on FOIB of Vietnamese millennials.

- H7: Hedonic value positively impacts on FOIB of Vietnamese millennials.

- H8: Fashion involvement positively impacts on FOIB of Vietnamese millennials.

- H9: There is a gender difference in terms of FOIB of Vietnamese millennials. 


\section{Research methodology}

In the empirical literature, both unstructured and structured methods were applied to identify antecedents of impulse buying behavior. As such a research is inexistent in Vietnam, we conducted a qualitative study to explore these external and internal factors contributing to fashion-oriented impulse behavior in the first step. The second step, we conducted a quantitative study to investigate the predictors of fashion-oriented impulse purchase.

- Step 1: To identify factors that might influence fashion impulse purchase by conducting four focus groups in Vietnam and at the same time to explore specific dimensions and items in connection with external and internal stimuli based on our literature review.

- Step 2: Specific factors and items captured in the qualitative study will be added to design a structured questionnaire. The questionnaire is composed of three parts: the first part is related to socio-demographic characteristics of our surveyed sample. The second part deals with the consumer behavior toward fashion items and the last part focuses on fashion impulse purchase. To measure the importance of each variable, we use the five-point Likert scale.

- Step 3: To run the factor analysis to extract factors and variables determining the antecedents of fashion impulse buying behavior and to test the relationship between external and internal factors and fashion-oriented impulse purchase.

Measurement scales were adapted from previous literature. In order to finalize the measurement scales to fit the proposed research model to the Vietnamese context, we conducted four focus groups with 12 participants/group who are young university students, a potential target segment of fast fashion retailers in Vietnam. This qualitative study explores the perception of all factors relating to fashion consumer behavior from Vietnamese young consumer perspectives. Results from the four focus groups indicate that all of external and internal stimuli proposed in the research model were also explored. It is worth noting that internal cues such as emotion, hedonic motive, and in particular fashion involvement were shared with excitement among these young participants. Interestingly, the unique item contributing to the "salespeople" factor that could not be found out in previous research is about the gender importance raised by a number of participants. Female participants insisted on getting advices about women clothes from female salespeople.

Based on the literature and the results of our qualitative study, we finalize our measurement scales exhibited in Table 1.

\subsection{Measurement instrument}

Table 1

Measurement instrument

\begin{tabular}{llll}
\hline \multicolumn{1}{c}{ Construct } & \multicolumn{1}{c}{ Factors } & Items & Source \\
\hline \multirow{5}{*}{ External stimuli } & Sensory cues & 6 & Mohan, Sivakumaran, and Sharma (2013) \\
& Visual merchandizing & 5 & Zhou and Wong (2003) \\
& Salespeople & 5 & Mohan et al. (2013) \\
& In-store promotions & 6 & Virvilaite (2011); R. Virvilaite et al. (2011) and Yang et al. (2011) \\
& Social stimuli & 4 & Turley and Milliman (2000); Miyuri (2017) and Luo (2005) \\
\hline \multirow{3}{*}{ Internal stimuli } & Fashion involvement & 6 & Aron (2004); Tigert et al. (1976) \\
& Positive emotion & 4 & Amanda and Brigitte (2003) \\
& Hedonic value & 5 & Babin et al. (1994) \\
\hline Impulse purchase & Fashion oriented impulse purchase & 6 & Park and Lennon (2006) \\
\hline
\end{tabular}

\subsection{Sampling method and data collection}

The survey was conducted during the period of June - November/2020, in Binh Duong city and its outskirts by face to face with 350 respondents with a convenience sample composed of young students and office workers, from 18-35-year old who represent the key target segment in Vietnam. We received 322 usable questionnaires.

\section{Research findings}

\subsection{Descriptive statistics}

Among 322 participants, male accounts for $31.7 \%$ and female ratio is $68.3 \%$. Regarding the age, almost participants (88.8\%) represent for Gen Y consumers who are from 18 to 25 . University students occupy $73 \%$ followed by office workers with $19.6 \%$. Income statistics show that $78.8 \%$ of the respondents have income from 5 million VND or below (from 1 to 5 million VND) while just $21.1 \%$ earns above 5 million VND. This is due to the fact that the study was conducted mostly with the majority of participants who are university students and they have quite low income (money earned from part-time jobs) or no income rather than the pocket money from their parents. Most of the participants (75\%) reported that they prefer to buy clothes in modern retailers such as supermarkets, shopping malls. This is due to the fact that young people prefer to shop at playful and fun environments where they can enjoy and experience the shopping trip, not just buying. A very important finding is that most of millennial consumers buy clothes on impulse with $94.7 \%$. 
Table 2

Descriptive analysis

\begin{tabular}{|c|c|c|c|}
\hline Variable & Group & Number (f) & Percentage $(\%)$ \\
\hline \multirow[t]{2}{*}{ Gender } & Male & 102 & 31.7 \\
\hline & Female & 220 & 68.3 \\
\hline \multirow[t]{3}{*}{ Age } & $18-20$ & 42 & 13 \\
\hline & $20-25$ & 244 & 75.8 \\
\hline & $25-30$ & 36 & 11.2 \\
\hline \multirow[t]{3}{*}{ Occupation } & High school student & 24 & 7.5 \\
\hline & University student & 235 & 73.0 \\
\hline & Worker/Employees & 63 & 19.6 \\
\hline \multirow{3}{*}{ Monthly Income } & $1,000,000 \mathrm{VND}-2,000,000 \mathrm{VND}$ & 126 & 39.1 \\
\hline & $2,000,000-5,000,000 \mathrm{VND}$ & 128 & 39.8 \\
\hline & $>5,000,000 \mathrm{VND}$ & 68 & 21.1 \\
\hline \multirow[t]{4}{*}{ Where to buy? } & Shopping clothes & 179 & 55.6 \\
\hline & Traditional markets & 81 & 25.2 \\
\hline & supermarkets & 59 & 18.3 \\
\hline & Shopping malls & 3 & .9 \\
\hline \multirow[t]{3}{*}{ Time to spend/visit } & $<1$ hour & 75 & 23.3 \\
\hline & Between 1-2 hours & 162 & 50.3 \\
\hline & $>2$ hours & 85 & 26.4 \\
\hline \multirow[t]{4}{*}{ Money to spend/visit } & $<200.000 \mathrm{VND}$ & 22 & 6.8 \\
\hline & $200.000-500.000 \mathrm{VND}$ & 161 & 50.0 \\
\hline & $500.000-1.000 .000 \mathrm{VND}$ & 100 & 31.1 \\
\hline & $>1.000 .000 \mathrm{VND}$ & 39 & 12.1 \\
\hline \multirow[t]{3}{*}{ Shopping time } & Morning & 23 & 7.1 \\
\hline & Afternoon & 87 & 27.0 \\
\hline & Evening & 212 & 65.8 \\
\hline \multirow[t]{3}{*}{ Shopping with whom } & Family members & 68 & 21.1 \\
\hline & Friends & 170 & 52.8 \\
\hline & Alone & 84 & 26.1 \\
\hline \multirow[t]{4}{*}{ Kind of items bought } & Top & 186 & 57.8 \\
\hline & Bottom & 75 & 23.3 \\
\hline & Accessories & 39 & 12.1 \\
\hline & Others & 22 & 6.8 \\
\hline \multirow[t]{9}{*}{ Information channel } & Internet, social network & 183 & 56.8 \\
\hline & Newspapers, fashion magazines & 17 & 5.3 \\
\hline & Billboards, leaflets, posters and catalogs & 16 & 5.0 \\
\hline & Events and fashion shows & 7 & 2.2 \\
\hline & Advertisement on TV & 8 & 2.5 \\
\hline & Colleagues, friends and families & 34 & 10.6 \\
\hline & By observing other trendy people & 22 & 6.8 \\
\hline & Paying a visit to the store & 27 & 8.4 \\
\hline & Store personnel's sales information & 8 & 2.5 \\
\hline \multirow[t]{3}{*}{ How often to buy on impulse? } & Most of the times & 149 & 46.3 \\
\hline & Sometimes & 156 & 48.4 \\
\hline & Never (I always have a plan) & 17 & 5.3 \\
\hline
\end{tabular}

Note: 1 USD $=22,000 V N D$

Table 3

EFA results

\begin{tabular}{|c|c|c|c|c|c|}
\hline & Factor & Eigenvalues & Mean & Corrected Item-Total & Cronbach's \\
\hline SENSORY CUES & & 8.991 & & & 0.823 \\
\hline - Nice ambience & .754 & & 3.72 & .430 & \\
\hline - Appealing color & .680 & & 3.72 & .481 & \\
\hline - Appealing aroma & .822 & & 3.60 & .448 & \\
\hline - Clean store & .736 & & 3.77 & .410 & \\
\hline - Nice touching (materials) & .706 & & 3.95 & .390 & \\
\hline VISUAL MERCHANDIZING & & 3.344 & & & 0.804 \\
\hline - Good visualization of merchandise (window, manne- & .703 & & 4.04 & .463 & \\
\hline - Product quality & .627 & & 4.39 & .350 & \\
\hline - Variety of products & .862 & & 4.05 & .419 & \\
\hline - Brand familiarity & .768 & & 3.89 & .378 & \\
\hline SALESPEOPLE & & 2.586 & & & 0.821 \\
\hline - Employees' professional uniform & .902 & & 3.59 & .335 & \\
\hline - Employees' attitude (friendly, courteous and helpful) & .705 & & 3.62 & .404 & \\
\hline - Employees know fashion trend. & .737 & & 3.68 & .387 & \\
\hline - Gender importance of sales people: female vendors & .875 & & 3.75 & .333 & \\
\hline IN-STORE PROMOTION & & 2.420 & & & 0.882 \\
\hline - In-store ads & .862 & & 3.66 & .532 & \\
\hline - Sales promotion & .695 & & 3.69 & .487 & \\
\hline - Membership card & .810 & & 3.73 & .467 & \\
\hline - Gifts & .793 & & 3.80 & .492 & \\
\hline - Direct discount (specific events) & .664 & & 3.75 & .420 & \\
\hline - Loyalty program & .728 & & 3.82 & .426 & \\
\hline
\end{tabular}


Table 3

EFA results (Continued)

\begin{tabular}{|c|c|c|c|c|c|}
\hline & Factor & Eigenvalues & Mean & Corrected Item-Total & Cronbach's \\
\hline SOCIAL STIMULI & & 2.194 & & & $\mathbf{0 . 8 0 7}$ \\
\hline - Perceived crowding & .718 & & 3.43 & .477 & \\
\hline - Interaction with other shoppers & .883 & & 3.46 & .468 & \\
\hline - Interaction with salespeople & .688 & & 3.20 & .383 & \\
\hline - Social status & .683 & & 3.47 & .429 & \\
\hline EMOTION & & 1.921 & & & 0.849 \\
\hline - It's fun to buy something new. & .684 & & 3.61 & .516 & \\
\hline - Even if I don't spend money, I still feel excited about & .879 & & 3.37 & .461 & \\
\hline - Shopping clothes is a pleasant activity for me. & .713 & & 3.72 & .447 & \\
\hline - I feel a sense of personal satisfaction when I wear & .830 & & 3.40 & .474 & \\
\hline HEDONIC VALUE & & 1.826 & & & 0.759 \\
\hline - I like to observe others in the store. & .620 & & 3.17 & .455 & \\
\hline - When I feel depressed, going shopping outfits can get & .725 & & 3.46 & .518 & \\
\hline - It seems that I explore a new world when I go shop- & .739 & & 3.43 & .501 & \\
\hline - Shopping outfits makes me happy. & .692 & & 3.58 & .484 & \\
\hline FAHSION INVOLVEMENT & & 1.336 & & & 0.853 \\
\hline - I am always keeping up with new trend, new fashion. & .739 & & 3.36 & .481 & \\
\hline - I keep my wardrobe up-to-date with the changing & .517 & & 3.39 & .485 & \\
\hline - Fashionable, attractive styling is very important to & .740 & & 3.52 & .499 & \\
\hline - Dressing well is an important part of my life. & .712 & & 3.42 & .417 & \\
\hline - If I have to choose between the two, I normally dress & .750 & & 3.19 & .402 & \\
\hline - I attach great importance to fashion clothing. & .793 & & 3.29 & .464 & \\
\hline - I would say fashion clothing is central to my identity & .563 & & 3.24 & .460 & \\
\hline \multicolumn{6}{|c|}{ KMO $=.836-$ Bartlett's Test of Sphericity: $x 2=6480.417, \bar{P}=.000-$ Total variance explained: $64.784 \%$} \\
\hline FASHION ORIENTED IMPULSE PURCHASE & & 3.023 & & & 0.803 \\
\hline - Most of the time, I buy clothes on impulse. & .692 & & 3.70 & .533 & \\
\hline - I enjoy purchasing new clothing that has just been & .644 & & 3.94 & .492 & \\
\hline - "If I see it, I like it and I will buy it" describes me. & .770 & & 3.62 & .576 & \\
\hline - I buy fashionable clothes on the spur of the moment, & .683 & & 3.75 & .559 & \\
\hline - When I go shopping for new clothes, I always over- & .735 & & 3.54 & .519 & \\
\hline - I normally buy other fashion pieces in addition to the & .727 & & 3.49 & .527 & \\
\hline
\end{tabular}

The reliability analysis showed favorable results. All of factors exhibited in Table 3 have a high degree of reliability in terms of Cronbach's Alpha ( $>0.7$ ) (Hair et al., 2014). After factor reduction, 8 factors remain with 5 external stimuli (Sensory cues, Visual merchandizing, Salespeople, In-store promotion, Social stimuli) and Internal stimuli (Emotion, Hedonic value, Fashion involvement).

\section{Impact of internal and external stimuli on fashion-oriented impulse purchase}

The reliability of fashion-oriented impulse purchase gives good results with Cronbach's Alpha $=0.803$.

Table 4

Regression results

\begin{tabular}{llccccccc}
\hline Model & & \multicolumn{2}{c}{$\begin{array}{c}\text { Unstandardized } \\
\text { Coefficients }\end{array}$} & $\begin{array}{c}\text { Standardized } \\
\text { Coefficients }\end{array}$ & t & Sig. & \multicolumn{2}{c}{ Collinearity Statistics } \\
\cline { 2 - 9 } & \multicolumn{1}{c}{ B } & Std. Error & Beta & & & Tolerance & VIF \\
\hline \multirow{2}{*}{ (Constant) } & .186 & .192 & & .970 & .333 & & \\
& Visual merchandizing & .111 & .041 & .112 & 2.723 & .007 & .753 & 1.328 \\
& Sensory cues & .154 & .037 & .169 & 4.195 & .000 & .786 & 1.273 \\
& Salespeople & -.043 & .029 & -.057 & -1.473 & .142 & .861 & 1.162 \\
1 & In-store promotion & .147 & .036 & .169 & 4.118 & .000 & .756 & 1.324 \\
& Social stimuli & -.015 & .036 & -.017 & -.415 & .678 & .741 & 1.349 \\
& Emotions & .231 & .031 & .304 & 7.394 & .000 & .751 & 1.331 \\
& Hedonic value & .246 & .036 & .299 & 6.784 & .000 & .656 & 1.525 \\
& Fashion Involvement & .138 & .039 & .151 & 3.508 & .001 & .683 & 1.463
\end{tabular}

Findings of the multiple regression showed in Table 4 clearly indicate the three factors representing internal stimuli are statistically significant. Emotion and Hedonic value appear as the most important predictors of fashion-oriented impulse purchase with the coefficients of 0.304 and 0.299 respectively at the significance level of 5\%. Fashion involvement seems less meaningful to affect impulse purchase among Vietnamese millennials compared with Emotion and Hedonic value as its coefficient is 0.151 . Regarding external stimuli, among five factors, only Sensory cues and In-store promotion is statistically significant with the same coefficient of 0.169 while Visual merchandizing, Salespeople and Social stimuli are not statistically significant. These findings indicate that these two external stimuli (Sensory cues and In-store promotion) have a strong influence fashionoriented impulse buying behavior among Vietnamese millennials when shopping for fashion products. 
The study shows another interesting factor which is gender that may have a strong effect in fashion-oriented impulse purchase. The relevant extant research works strongly prove that female consumers are likly to be more impulsive than male buyers. $T$ test is used in the study to determine gender differences related to fashion impulse purchase. T-test results confirm that there is a big difference in fashion impulse purchase among male and female Vietnamese millennials (Table 5). It can be seen that the Levene's Test for Equality of Variances has a Sig value of $0.048<0.05$. Thus, at $95 \%$ confidence level, the variances between two genders are not uniform. Also, the Equal variances not assumed with $\mathrm{Sig}=0.068<0.1$ confirms that between gender groups (male and female), there is a difference in regard to the impulse purchase behavior toward fashion products.

Table 5

Relationship between gender and fashion-oriented impulse purchase

\begin{tabular}{lccccc}
\hline & Gender & $\mathrm{N}$ & Mean & Std. Deviation & Std. Error Mean \\
\hline \multirow{2}{*}{ Fashion Oriented IP } & Male & 102 & 3.5654 & .74431 & .07370 \\
& Female & 220 & 3.7250 & .68265 & .04602 \\
\hline
\end{tabular}

Table 6

Independent Samples Test

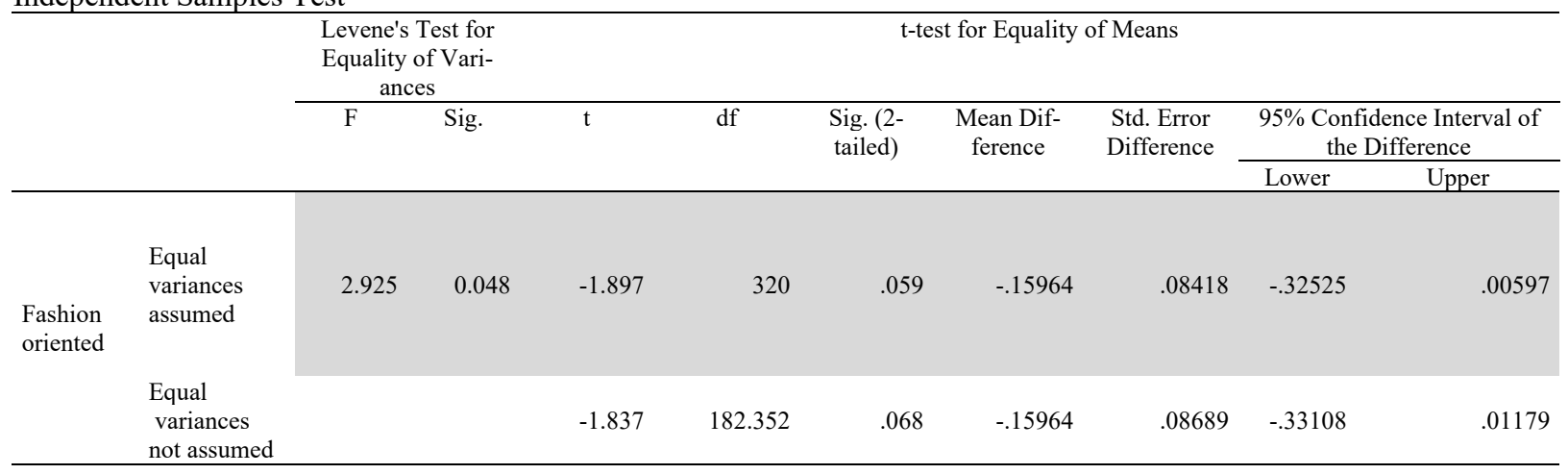

In a nutshell, our results reflect the situation of the fast fashion landscape in Vietnam. The fierce competition between global and local fast fashion retailers have aggressively launched sales incentives and other promotional campaigns mainly at the points of purchase to attract patronage and increase sales through impulse purchase.

\section{Discussion}

The research findings show that Emotion and Hedonic values appear as the most important predictors of fashion-oriented impulse purchase of Vietnamese millennials. This result concurs with the finding of Ballantine, Parsons, and Comeskey (2015) that highligted variables that fashion retailers can use within the store and that can produce comfortable environment and thus can increase impulse purchase probability of the shoppers. In fact, when shoppers have good emotional feelings while entering the store, they are likely to have more pleasure and fun and this results in spending more time and money (Khandai et al., 2012; Lins et al., 2015). The empirical studies conducted by Chang, Eckman, and Yan (2011) revealed that in the Vietnamese context, young consumers having more positive emotional responses to the retail environment are more likely to buy more on impulse. Also, another important aspect to trigger impulsive consumption of yougn consumers is that retailers should find the ways to create a pleasing environment where shoppers can feel their important role or "the face" and thus can touch their hedonisim that leads them to buy more impulsively. Regarding external stimuli, Sensory cues and In-store promotion are extremely crucial. This finding indicates that these two external drivers have strong influence on fashion-oriented impulse buying behavior of Vietnamese millennials. They seem very close to case of Vietnam, an emerging market having the largest young and middle-income consumers who tend to be impulsively attracted by in-store promotion activities when they buy fast fashion products. Furthermore, these young consumers nowadays are much more attracted by atmospherics or sensory cues that can lead to create excitement and pleasure while shopping. Our findings are consistent with previous research work results as In-store promotion and Sensory cues are important for fashion sellers to increase sales through impulse purchase at the point of purchase (Hultén, 2012; Mattila \& Wirtz, 2001; Morrison et al., 2011; Nanda, 2013; Zhou \& Wong, 2003).

\section{Conclusion}

Our research on factors determining impulse purchase behavior and their direct linkage to fast-fashion oriented impulse purchase among Vietnamese millennials comes up with the two key findings. First, both external and internal factors that can stimulate impulse purchase behavior perceived by the Vietnamese millennials. Internal stimuli (Emotion and Hedonic value) appear the most powerful predictors of fashion-oriented impulse purchase. Meanwhile, external factors such as In-store promotion and Sensory cues are less influential in affecting impulse purchase. Findings in this research are meaningful for both global and local fashion brands targeting Vietnamese millennials. Specifically, fashion retailers should not only improve their 
in-store environment but also know how to contribute positive emotions, hedonic value and raise fashion involvement among young customers and thus can trigger their impulse purchase. This exploratory study results will help fashion retailers efficiently design retailing mix strategy in order to operate with more success in a highly competitive market.

\subsection{Managerial implications}

The findings from our study reveal that in Vietnam, a great number of millennials experience impulse purchase when shopping in fast fashion stores. Most importantly, their fashion-oriented impulse purchase is strongly influenced by both internal cues, in particular Emotion and Hedonic value and external cues such as Sensory cues and In-store promotion. This implies that fashion retailers need to better manage both internal and external stimuli that can trigger the buying impulsiveness among the youth segment. Specifically, our empirical tests indicate that managers should well take care of these key factors when designing a holistic marketing strategy.

As internal stimuli, particularly Emotion and Hedonic value contribute significantly to fashion-oriented impulse purchase compared with external stimuli among young consumers in Vietnam, fast fashion retailers need to concentrate their marketing efforts to enhance these internal factors. Emotion is revealed as the most influential factor on impulsive consumption of Vietnamese young consumers. This means that young consumers' impulse buying is emotionally driven, they first like and then buy fashion products. Therefore, fashion retailers should improve their stores' look and ambience in an attractive way in order to provide potential customers good feelings and thus can engage them to buy apparels on impulse.

Along with positive emotion that fashion retailers should bring to their customers, Hedonic value becomes tremendously crucial in delivering the first impression and long-term relationship with the Vietnamese young buyers. This suggests that fashion retailers need not only make their shopping place enjoyable but also create unforgettable purchase experiments for customers during their store visit.

Besides, similar to the two internal stimuli (Emotion and Hedonic value), Fashion Involvement also predicts impulse purchase among young consumers. This implies that fashion store managers need to elaborate effective integrated marketing communication strategies at their points of purchase to enhance stronger interest and consciousness in fashion trend and fashion goods among potential fashion consumers in Vietnam.

Regarding external stimuli as antecedents of fashion impulse buying behavior, the two factors which are statistically significant are In-store promotion and Sensory cues. In fact, the former factor shows its attractiveness to Vietnamese millennials who have been increasingly responding to interesting different sales incentives in making their impulse buying decisions. Despite their income remains quite moderate, these young people tend become more and more fashionable and fashion clothing is considered as a significant part of their life. To afford fashion items, they are excited about In-store promotion such as coupons, special discounts, and other loyalty programs. Therefore, fashion retail managers should consider to design the appealing in-store sales programs that can highly trigger unplanned purchase. The latter factor (Sensory cues) perceived extremely powerful in creating appealing atmospherics and enjoyable shopping experience for young customers. Therefore, fashion retailers targeting this segment should improve their store environment by carefully design fashionable and trendy items exposed to the lighting, scents, and colors.

Last but not least, as there is a big difference of both genders toward fashion-oriented impulse purchase and for this reality, fashion retailers should invest wisely their differentiation strategy for the two distinct male and female segments in order to enhance their impulse purchase.

\subsection{Research limitations and future research directions}

First, the survey was conducted with a convenience sample with respondents representing the target market of fast fashion from 18-35 years of age and they are living in Binh Duong city, located in the south of Vietnam where retailing landscape in general and fashion retailing specifically have not been strongly developed in comparison with Ho Chi Minh city with the highest income per capita and consumption level in the country. Although, our convenience sample is demonstrated adequate in this exploratory study, a larger sample covering in other larger cities like Ho Chi Minh and Hanoi would be examined in the future research.

Second, our empirical study focuses on fashion-oriented impulse buying among the younger cohort of Vietnamese consumers who are mostly students from 18 to 25 years of age whom do not have high income and that might limit the perception on factors contributing to fashion impulse purchase. Therefore, the future study will expand to the older cohort of Gen $\mathrm{Y}$ who are from 25 to 35 with more independent life and higher income and more importantly having tremendous needs in fastfashion goods consumption.

Third, following a great number of authors such as Nanda (2013); Yu and Bastin (2010), this research investigates only the direct relationship between external and internal stimuli and fashion-oriented impulse purchase while ignoring the indirect 
relationships of each stimuli especially internal stimuli and fashion-oriented impulse purchase behavior. To understand deeply the complexity of the interaction of different factors getting involved in the impulse buying process and behavior, the future studies will examine these indirect relationships via moderators such as emotion or fashion involvement that are the most studied in the past few years (Aron, 2004; Park \& Lennon, 2006).

\section{References}

Agarwal, V. (2015). A study of demographic factors influence on consumers' impulse purchase behavior. CLEAR International Journal of Research in Commerce \& Management, 6(11), 59-62.

Amanda, C., \& Brigitte, B. (2003). Gender differences in cognitive and affective impulse buying. Journal of Fashion Marketing \& Management, 7(3), 282-295.

Aron, O. C. (2004). Fashion clothing consumption: antecedents and consequences of fashion clothing involvement. European Journal of Marketing, 38(7), 869-882. doi:10.1108/03090560410539294

Avinash, K., \& Chinmaya, K. (2009). Consumers' perceptions: an analytical study of influence of consumer emotions and response. Direct Marketing: An International Journal, 3(3), 186-202. doi:10.1108/17505930910985134

Babin, B. J., Darden, W. R., \& Griffin, M. (1994). Work and/or fun: measuring hedonic and utilitarian shopping value. Journal of consumer research, 20(4), 644-656.

Balaji, M. K., \& Babu, M. K. (2015). The Theoritical Framework On Factors Affecting Consumer Impulsive Buying Behaviour In Retail Environment. International Journal of Scientific Research and Management, 3(3).

Ballantine, P. W., Parsons, A., \& Comeskey, K. (2015). A conceptual model of the holistic effects of atmospheric cues in fashion retailing. International Journal of Retail \& Distribution Management, 43(6), 503-517. doi:10.1108/IJRDM-022014-0015

Barnes, L., \& Greenwood, G. (2010). Fast fashion in the retail store environment. International Journal of Retail \& Distribution Management, 38(10), 760-772. doi:10.1108/09590551011076533

Beatty, S. E., \& Ferrell, M. E. (1998). Impulse buying: Modeling its precursors. Journal of retailing, 74(2), $169-191$.

Bhatti, K. L., \& Latif, S. (2014). The Impact of Visual Merchandising on Consumer Impulse Buying Behavior. Eurasian Journal of Business and Management, 2(1), 24-35.

Chang, H.-J., Eckman, M., \& Yan, R.-N. (2011). Application of the Stimulus-Organism-Response model to the retail environment: the role of hedonic motivation in impulse buying behavior. The International Review of Retail, Distribution and Consumer Research, 21(3), 233-249. doi:10.1080/09593969.2011.578798

Cinjarevic, M., Tatic, K., \& Petric, S. (2011). See it, like it, buy it! Hedonic shopping motivations and impulse buying. Economic Review: Journal of Economics and Business, 9(1), 3-15.

Clover, V. T. (1950). Relative importance of impulse buying in retail stores. Journal of Marketing, 15(1), 66-70.

Cobb, C. J., \& Hoyer, W. B. (1986). Planned Versus Impulse Purchase Behavior. Journal of Retailing, 62(4), 384.

Donovan, R. J., Rossiter, J. R., Marcoolyn, G., \& Nesdale, A. (1994). Store atmosphere and purchasing behavior. Journal of Retailing, 70(3), 283-294.

Duarte, P., Raposo, M., \& Ferraz, M. (2013). Drivers of snack foods impulse buying behaviour among young consumers. British Food Journal, 115(9), 1233-1254.

Geoff, B., \& Clive, N. (1998). Impulse purchasing: a qualitative exploration of the phenomenon. Qualitative Market Research: An International Journal, 1(2), 99-114.

$\mathrm{Hu}$, K.-L., \& Shiau, R.-J. (2015). An empirical study of purchase intention of fast fashion goods in Taiwan. International Journal of Organizational Innovation, 7(3), 126-144.

Hultén, B. (2012). Sensory cues and shoppers' touching behaviour: the case of IKEA. International Journal of Retail \& Distribution Management, 40(4), 273-289.

Kacen, J. J., \& Lee, J. A. (2002). The influence of culture on consumer impulsive buying behavior. Journal of Consumer Psychology, 12(2), 163-176.

Khandai, S., Agrawal, B., \& Gulla, A. (2012). Visual Merchandising As An Antecedent To Impulse Buying?: An Indian Perspective. International Journal of Business and Management Studies, 1(1), 267-277.

Khare, A., \& Rakesh, S. (2010). Predictors of fashion clothing involvement among Indian youth. Journal of Targeting, Measurement and Analysis for Marketing, 18(3-4), 209-220.

Kotler, P. (1973). Atmospherics as a marketing tool. Journal of Retailing, 49(4), 48-64.

Lee, G. Y., \& Yi, Y. (2008). The effect of shopping emotions and perceived risk on impulsive buying: the moderating role of buying impulsiveness trait. Seoul Journal of Business.

Liao, S. L., Shen, Y. C., \& Chu, C. H. (2009). The effects of sales promotion strategy, product appeal and consumer traits on reminder impulse buying behaviour. International Journal of Consumer Studies, 33(3), 274-284.

Lins, S., Dóka, Á., Bottequin, E., Odabašić, A., Pavlović, S., Merchán, A., . . Hylander, F. (2015). The effects of having, feeling, and thinking on impulse buying in European adolescents. Journal of International Consumer Marketing, 27(5), 414-428. doi:10.1080/08961530.2015.1027028

Luo, X. (2005). How Does Shopping With Others Influence Impulsive Purchasing? Journal of Consumer Psychology, 15, 288-294. doi:10.1207/s15327663jcp1504_3

Mattila, A. S., \& Wirtz, J. (2001). Congruency of scent and music as a driver of in-store evaluations and behavior. Journal of Retailing, 77(2), 273-289. 
Mattila, A. S., \& Wirtz, J. (2008). The role of store environmental stimulation and social factors on impulse purchasing. Journal of Services Marketing, 22(7), 562-567.

Maymand, M. M., \& Ahmadinejad, M. (2011). Impulse buying: the role of store environmental stimulation and situational factors (An empirical investigation). African Journal of Business Management, 5(34), 13057.

Miyuri, S. (2017). Underdog effects: the role of consumption domain and retail crowding. Journal of Consumer Marketing, 34(5), 384-392. doi:10.1108/JCM-07-2016-1872

Mohan, G., Sivakumaran, B., \& Sharma, P. (2013). Impact of Store Environment on Impulse Buying Behavior. Australia, Australia/Oceania.

Morgan, L. R., \& Birtwistle, G. (2009). An investigation of young fashion consumers' disposal habits. International Journal of Consumer Studies, 33(2), 190-198.

Morrison, M., Gan, S., Dubelaar, C., \& Oppewal, H. (2011). In-store music and aroma influences on shopper behavior and satisfaction. Journal of Business Research, 64(6), 558-564.

Nanda, A. (2013). Impulse buying of apparels. International Journal of Research in Commerce \& Management, 4(2), 170176.

Nguyen, Jung, K., Lantz, G., \& Loeb, S. G. (2003). An exploratory investigation into impulse buying behavior in a transitional economy: A study of urban consumers in Vietnam. Journal of International Marketing, 11(2), 13-35.

Park, J., \& Lennon, S. J. (2006). Psychological and environmental antecedents of impulse buying tendency in the multichannel shopping context. Journal of Consumer Marketing, 23(2), 58-68. doi:10.1108/07363760610654998

Parker, R. S., Simmers, S. C., \& Schaefer, A. D. (2014). An exploratory study: Gen Y males and their attitudes toward fashion. Academy of Marketing Studies Journal, 18(2), 79-89.

Patil, P., \& Agadi, R. (2016). Impact of visual merchandising on young customers ${ }^{\text {ee }}$ apparel impulse buying behaviour. International Journal of Advancement in Engineering, Technology, Management \& Applied Science, 3(1), 187-199.

Peck, J., \& Childers, T. L. (2006). If I touch it I have to have it: Individual and environmental influences on impulse purchasing. Journal of Business Research, 59(6), 765-769. doi:10.1016/j.jbusres.2006.01.014

Piron, F. (1991). Defining Impulse Purchasing. Advances in Consumer Research, 18(1), 509-514

Pornpitakpan, C., Yuan, Y., \& Han, J. H. (2017). The effect of salespersons' retail service quality and consumers' mood on impulse buying. Australasian Marketing Journal (AMJ), 25(1), 2-11. doi:https://doi.org/10.1016/j.ausmj.2016.12.003

Ramanathan, S., \& Menon, G. (2006). Time-Varying Effects of Chronic Hedonic Goals on Impulsive Behavior. Journal of Marketing Research 43(4), 628-641.

Ridgway, N. M., Kukar-Kinney, M., \& Monroe, K. B. (2008). An expanded conceptualization and a new measure of compulsive buying. Journal of Consumer Research, 35(4), 622-639.

Robert, F. R. (2001). The role of values in servant leadership. Leadership \& Organization Development Journal, 22(2), 7684. doi:10.1108/01437730110382631

Rook, \& Fisher, R. (1995). Normative influences on impulsive buying behavior. Journal of Consumer Research, 22(3), 305313.

Rook, \& Hoch, S. J. (1985). Consuming Impulses. Advances in Consumer Research, 12(1), 23-27.

Rook, D. W. (1987). The buying impulse. Journal of consumer research, 14(2), 189-199.

Scheier, M. F., \& Carver, C. S. (1988). A Model of Behavioral Self-Regulation: Translating Intention into Action. In L. Berkowitz (Ed.), Advances in Experimental Social Psychology (Vol. 21, pp. 303-346): Academic Press.

Sharma, P., Sivakumaran, B., \& Marshall, R. (2006). Investigating Impulse Buying and Variety Seeking: Towards a General Theory of Hedonic Purchase Behaviors. Advances in Consumer Research, 33(1), 388-389.

Sharma, P., Sivakumaran, B., \& Marshall, R. (2010). Exploring impulse buying and variety seeking by retail shoppers: towards a common conceptual framework. Journal of Marketing Management, 26(5-6), 473-494. doi:10.1080/02672570903485097

Tigert, D. J., Ring, L. J., \& King, C. W. (1976). Fashion involvement and buying behavior: A methodological study. ACR North American Advances.

Turley, L. W., \& Milliman, R. E. (2000). Atmospheric Effects on Shopping Behavior: A Review of the Experimental Evidence. Journal of Business Research, 49(2), 193-211. doi:https://doi.org/10.1016/S0148-2963(99)00010-7

Verplanken, B., \& Herabadi, A. (2001). Individual differences in impulse buying tendency: Feeling and no thinking. European Journal of Personality, 15(S1), S71-S83.

Virvilaite, R., Saladienè, V., \& Žvinklyte, J. (2011). The impact of external and internal stimuli on impulse purchasing. Economics \& Management, 16.

Warrington, P., \& Shim, S. (2000). An empirical investigation of the relationship between product involvement and brand commitment. Psychology and Marketing, 17(9), 761-782.

Weinberg, P., \& Gottwald, W. (1982). Impulsive consumer buying as a result of emotions. Journal of Business Research, 10(1), 43-57. doi:https://doi.org/10.1016/0148-2963(82)90016-9

Wong, N. Y., \& Bagozzi, R. P. (2005). Emotional intensity as a function of psychological distance and cultural orientation. Journal of Business Research, 58(4), 533-542. doi:https://doi.org/10.1016/S0148-2963(03)00144-9

Yang, D. J., Huang, K. C., \& Feng, X. (2011). A study of the factors that affect the impulsive cosmetics buying of female consumers in Kaohsiung. International Journal of Business and Social Science, 2(24), 275-282.

Youn, S., \& Faber, R. J. (2000). Impulse Buying: Its Relation to Personality Traits and Cues. Advances in Consumer Research, 27(1), 179-185. 
Yu, C., \& Bastin, M. (2010). Hedonic shopping value and impulse buying behavior in transitional economies: a symbiosis in the Mainland China marketplace. Journal of Brand Management(2), 105.

Zhou, L., \& Wong, A. (2003). Consumer Impulse Buying and In-Store Stimuli in Chinese Supermarkets. Journal of International Consumer Marketing, 16(2), 37-54. doi:10.1 300/J046v 16n02_03

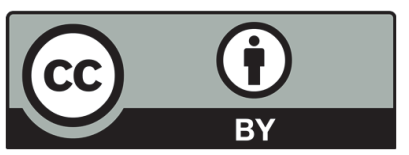

(C) 2021 by the authors; licensee Growing Science, Canada. This is an open access article distributed under the terms and conditions of the Creative Commons Attribution (CC-BY) license (http://creativecommons.org/licenses/by/4.0/). 